\title{
Türkçe Öğretmeni Adaylarının Öğretim Materyali Olarak Amaca Uygun Yazdıkları Metinlerin Değerlendirilmesi*
}

\section{Hatice COŞKUN**}

Öz: $\mathrm{Bu}$ çalışmanın amacı Türkçe öğretmen adaylarının eğitim ortamlarında ihtiyaç duydukları niteliklerde metinler bulamadıklarında kendilerinin amaca uygun metinler oluşturabilme becerilerinin belirlenmesidir. Nitel araştırma yöntemine göre düzenlenen bu araştırmanın çalışma grubunu üç farklı üniversitenin eğitim fakültesi Türkçe öğretmenliği bölümü dördüncü sınıf öğrencileri oluşturmaktadır. Çalışma grubunda 130 Türkçe öğretmen adayı yer almaktadır. Yazma formlarının değerlendirilmesinde araştırmacı tarafından geliştirilen metin değerlendirme formları kullanılmıştır. Öğretmen adaylarının yazdıkları metinler incelendiğinde genel olarak başlık, anlaşılırlık ve akıcılık, tutarlılık ve sınıf düzeyine uygunluk açısından başarılı oldukları görünse de başarısız olunan metin sayısı bu konuda ciddi problemler olduğunu göstermektedir. Metinler amaç ve ana fikri verme şekline göre değerlendirildiğinde ise amaç ve ana fikrin daha çok sezdirilerek verilmeye çalışıldığ görülmektedir. Öğretmen adayları amaca uygun metin yazma konusunda sorunlar yaşamaktadır. Bu sorunların çözümünde Türkçe öğretmeni yetiştirme programlarında görev yapan öğretim üyelerine, araştırmacılara, özellikle de öğretmen adaylarına önemli görevler düşmektedir. Yazma eğitiminde uygulamaya yönelik çalışmalar yapılması ve öğretim materyali olarak metinlerin taşıması gereken özellikler ve gerektiğinde bu özelliklere uygun metin yazma hususunda öğretmen adaylarının yeterince eğitim alması gerekmektedir.

*Bu çalışma araştırmacının “Türkçe Öğretmeni Adaylarının Amaca Uygun Metin Yazma Becerilerinin Belirlenmesi" adlı doktora tezinden üretilmiştir.

**Yrd. Doç. Dr. Hatice COŞKUN, Yüzüncü Yıl Üniversitesi, Eğitim Fakültesi, Türkçe ve Sosyal Bilimler Eğitimi Bölümü, Türkçe Eğitimi ABD, Van, haticecoskun@yyu.edu.tr

$\begin{array}{lll}\text { Gönderim:17.10.2016 } & \text { Kabul:05.02.2017 } & \text { Yayın:03.04.2017 }\end{array}$


Anahtar kelimeler: Türkçe öğretmen adayları, amaca uygun metin yazma, metinler

\title{
The Evaluation of the Texts Writing in Candidates of Turkish Teachers as a Teaching Material Appropriate to the Aim
}

\begin{abstract}
The aim of the this research is determining Candidates of Turkish Teachers' qualities on writing that is appropriate texts when they need them in educational areas if they couldn't find texts they need. Three different universities of education departmant's Turkish Teaching 4th grade students create this research according to qualitative research method. In this research group, there are 130 candidates of Turkish Teachers. Evaluating of text forms developed by researchers are used in evaluating writing forms. Even if The Candidate of Turkish Teachers are generally successful in intelligibility, accuracy, appropriately of class level when their texts are searched. The number of failure texts show that there are valid problems. When text purpose and objective assessment based on the route of the main idea and the main idea is seen that tried to be more intuit. Teacher candidates is having trouble about the subject of writing text which is appropriate to aim. In this solution of the problem, the faculty members working in the Turkish Teacher Training programs, researchers, especially the candidate teachers have important roles. Conducting studies for application in writing teaching and learning material must have the features of the text and it is thought that if it is necessary, candidate teachers should obtain enough training about writing a text.
\end{abstract}

Keywords: Candidates of Turkish teachers, writing text appropriate to the aim, texts. 


\section{Giriş}

İlk okuma yazma süreciyle birlikte edinilmeye başlayan ve gelişerek devam eden yazma becerisi insanların duygularını, düşüncelerini, iletilerini hedef kitleye yazı yoluyla ulaştırmasını sağlamaktadır. Bu biçimler birbiriyle ilişkili olarak bir araya geldiğinde anlam kazanır. Yazmayla ilgili yapılan en genel tanım ise duygu, düşünce ve isteklerin kurallara uygun olarak yazılı bir şekilde anlatılmasıdır (Güneş, 2013). Burada önemli olan anlatılmak istenenlerin yazma kurallarına uygun olarak bir araya getirilmesi ve anlamlandırılmasıdır. Yazılanların güzel ve etkili olması daha sonraki süreçlerde yazma becerisinde ulaşılacak üst bir düzeyde gerçekleşmektedir. Üst düzey yazma becerisi Demirel'in (1999) de belirttiği gibi mekanik bir süreç değil eleştirel bir düşünme sürecidir.

Her yazı hedef kitlesine bir ileti göndermek amacıyla kaleme alınmaktadır. Metinsellik ölçütlerinden biri olan amaçlılık metnin bir amaca hizmet etmek için yazılmış olması (Erkul, 2007) bir diğer deyiş̧le yazarın vermek istediği mesajı tam olarak yazıya yansitabilmesidir (Pilav ve Ünalan, 2012). Bu da bizi yazmaya iten, okuyucumuza iletmek istediğimiz temel düşüncedir (Özdemir ve Binyazar, 2002). Öğrenme amacıyla metne yönelen okurun okuduğunu anlaması için hem yazarın hem de okurun aynı yönde beklentilerinin olması gerekir (Karatay, 2007).

Gerek amaca uygun metin yazma becerisinin gerekse temel düzeyde yazma becerisinin kazandırılmasında etkili olan faktörlerden en çok üzerinde durulanı öğretmendir. Öğretmenlerin bu beceriyi kazandırmada aldıkları eğitim ve mesleki yeterlikleri önemlidir. 
http://dx.doi.org/10.23891/efdyyu.2017.18

ISSN:1305-020

Mesleki bilgi ve öğretmenlik alan bilgisi alarak yetişen öğretmenlerin Türkçe derslerinde istenen başarıyı sağlayacağı düşünülmektedir.

Türkçenin istenilen düzeyde öğrenilmesi bireylere verilecek eğitimle mümkündür. $\mathrm{Bu}$ eğitim de Türkçe öğretmenlerinin çabalarıyla gerçekleşeceğinden Türkçe öğretmeni yetiştiren programların niteliği öne çıkmaktadır (Çoban, 2010). Nitelikli bir öğretmen yetiştirme programının öğretme sürecinde hitap edilecek öğrenci düzeyine ve öğrencilerin ihtiyaçlarına uygun eğitim vermesi gereklidir. Bratcher ve Strable'in (1994) de üzerinde durduğu gibi öğretmenlerin yazma öğretiminde kendilerini yeterli hissedebilmeleri için önce yazmada rahat ve güvende hissetmeleri gerekmektedir. Öğretmenler yazmanın gerçekten nasıl bir süreç olduğunu bilene kadar öğrencilerine yazmayı asla iyi öğretemeyeceklerdir (Bratcher ve Strable'den aktaran Street ve Stong, 2009).

Türkçe öğretmenliği programından mezun olan öğretmenlerin gerek üniversitede aldıkları eğitim gerekse bireysel çabaları sonucunda yazma becerisinde yeterli bir düzeye ulaşmış olması ve bu becerilerini eğitim ortamlarına aktarabilmeleri beklenir. Türkçe öğretmenleri öğretim ortamlarında ders kitaplarındaki metinleri yetersiz gördügünde ya da öğrencilere öğretmek istediği bir konu, kavram ya da kazandırmak istediği bir düşünce olduğunda bu becerilerini devreye koyabilmelidir. Gerek derse hazırlık metni, gerekse kazanımlara uygun bir metin yazabilmeli; kelime öğretiminde, dil bilgisini metne dayalı öğretmede kullanılabilecek bir metin hazırlayıp bu metinleri etkin bir şekilde kullanabilmelidir. Oysa lisans programlarındaki yazılı anlatımla ilgili ders içeriklerinde bu konuya değinilmemektedir.

Yazma eğitimi ile ilgili çalışmalar incelendiğinde Türkçe öğretmenlerinin ya da öğretmen adaylarının yazma becerilerinin amaca uygun metin yazma; bir diğer deyişle ihtiyaç duyduklarında derste kullanmak üzere sınırları belirlenmiş metinler yazma 
http://dx.doi.org/10.23891/efdyyu.2017.18

ISSN:1305-020

becerilerini belirlemeye yönelik doğrudan bir çalışmanın olmadığı görülmektedir. Yapılan çalışmalar genellikle planlı yazma uygulamaları, yazdırılan metinlerin genel özelliklerini belirleme, yazmaya yönelik tutumu belirleme ya da yazılı anlatımdaki başarı durumlarını tespit etmeye yöneliktir. Öğretmen adaylarıyla yazma becerisine yönelik yapılan çalışmalar incelendiğinde bazı çalışmalarda konunun sınırlandırılamadığı, içeriğin amaca göre oluşturulamadığı, düşüncelerin dağınık olduğu ve metinlere başlık vermede sorunlar yaşandığı belirlenmiştir (Bozkurt, 2009; Anılan, Kaya, Bayrak ve Kaynaş, 2010; Arıcı, 2008). Bazı çalışmalarda ise bunun aksi yönde sonuçlar elde edilmiş, metinlerin yeterli olduğu, metin olma özelliklerini taşıdığı sonuçlarına ulaşılmıştır (Göçer, 2010). Bazı araştırma sonuçlarında da öğretmen adaylarının yazmaya karşı olumlu tutuma sahip oldukları, planlı yazma modellerine göre hazırlanan yazma etkinliklerinin yazılı anlatımda başarıyı arttırdığı ve yazmaya yönelik olumlu tutum geliştirdiği sonucuna ulaşılmıştır (Göçer, 2010; Ceran, 2013; Bağc1, 2007; Ülper, 2008; Duman, 2005).

Ayrıca öğretim ortamlarında öğretmenler araç-gereç sıkıntısı çekmekte özellikle de ders kitapları ile ilgili problemler yaşamaktadır. Ders kitaplarına seçilen metinler içerik açısından zayıf, öğrenci seviyesine uygun olmayan özellikler göstermektedir (Karatay, 2010; Ülper, 2011; Erdem ve Başaran, 2010; Çeçen ve Aytaş, 2008; Uygun ve Katranc1, 2013; Güven, 2011; Gündoğdu, 2011).

Alanda yapılan çalışmalar dikkate alındığında yazılı anlatım, yaratıcı yazma, belli metin türlerinde yazma konusunda araştırmalar olduğu görülmektedir. Fakat Türkçe eğitiminde bir metnin amaca uygun nitelikte oluşturulmasına dair araştırmaya rastlanmamıştır. Bu çalışmayla ortaya konmaya çalışılan Türkçe öğretmeni adaylarının eğitim ortamlarında ihtiyaç duydukları niteliklere uygun metin yazma yeterliklerinin belirlenmesi konuya dikkat çekecektir. Çünkü bu işin uygulayıcıları olan öğretmenler, ders işleme 
http://dx.doi.org/10.23891/efdyyu.2017.18

ISSN:1305-020

sürecinde, sinavlara soru hazırlarken ya da belli bir konuda sinıfa metin götürmeleri gerektiğinde hazır metinlerden faydalanamıyorlarsa amaçları doğrultusunda metinler oluşturabilmelidir. $\mathrm{Bu}$ doğrultuda araştırmanın öğretmen eğitiminde eğitim amaçlı metin yazma becerisinin önemine dikkat çekerek eğitim ortamlarının ve programlarının gözden geçirilmesine zemin hazırlayacağl düşünülmektedir. Ayrıca Türkçe öğretmenliği programındaki yazma eğitimine yönelik derslerde uygulamaya ağırlık verilmesi gerektiğine dikkat çekecektir.

Çalışmada Türkçe öğretmen adaylarının eğitim ortamlarında ihtiyaç duydukları niteliklerde, dersin hedefleri doğrultusunda amaca uygun metinler oluşturabilme becerilerinin belirlenmesine çalışılmıştır. Araştırmanın alt amaçları ise şöyledir:

Öğretmen adaylarının amaca uygun yazdıkları metinlerin

1. Öğretim materyali olarak metne başlik verme,

2. Öğretim materyali olarak hazırlanan metinlerin anlaşılırlı̆̆ ve akıcılığg,

3. Öğretim materyali olarak oluşturulan metinlerin sınıf düzeyine uygunluğu,

4. Öğretim materyali olarak hazırlanan metinlerin tutarlılı̆̆1,

5. Öğretim materyali olarak hazırlanan metinlerde amaç ve ana fikri sezdirme şekli açısından değerlendirilmesidir

\section{Yöntem}

$\mathrm{Bu}$ çalışma gözlem, görüşme ve doküman inceleme gibi nitel veri toplama yöntemlerinin kullanıldığg, algıların ve olayların doğal ortamda gerçekçi ve bütüncül bir biçimde ortaya konmaya çalışıldığı nitel araştırma yöntemine göre düzenlenmiştir (Yıldırım ve Şimşek, 2008). Nitel veri toplama yöntemlerinden doküman analizinin kullanıldığı bu çalışmada öğretmen adaylarının yazdıkları metinler incelenmiştir. 
http://dx.doi.org/10.23891/efdyyu.2017.18

ISSN:1305-020

Bailey (1982) doküman incelemede dört aşamadan bahseder: Veri setinin

belirlenmesi, kategorilerin geliştirilmesi, analiz biriminin saptanması, verilerin sayısallaştırılması. Araştırmacı kullandığı kategoriler ve analiz birimine göre bulduğu sonuçları var ya da yok (ilgili kategorinin dokümanda olup olmadığı), şeklinde nicelleştirilebilir. Güvenirlik için elde edilen verilerin açık ve tutarlı sunulması ve veri analizi sürecinde bir başka araştırmacının teyidinin alınması önerilmektedir (Bailey'den aktaran Cansız Aktaş, 2014, s. 363) Öğretmen adaylarının yazdıkları metinlerin analizinde bahsedilen süreç izlenmiş ve analizler bu doğrultuda yapılmıştır.

Çalışma grubu: Araştırmanın çalışma grubunu 2013-2014 eğitim-öğretim yılında Gazi Üniversitesi Gazi Eğitim Fakültesi, Mustafa Kemal Üniversitesi Eğitim Fakültesi ve Yüzüncü Yıl Üniversitesi Eğitim Fakültesi Türkçe Öğretmenliği Bölümlerinin 4. sınıf ögrencileri oluşturmaktadır. Çalışma grubunun seçiminde verilerin toplanmasındaki kolaylık, ekonomiklik ve kontrolün sağlanması için araştırmacının kolaylıkla ulaşabileceği gruplar tercih edilmiştir. $\mathrm{Bu}$ nedenle kolay ulaşılabilir durum örneklemesi yoluna gidilmiştir. $\mathrm{Bu}$ örnekleme yöntemi araştırmaya hız ve pratiklik kazandırır. Çünkü bu yöntemde araştırmacı yakın ve erişilmesi kolay olan bir durumu seçer (Yıldırım ve Şimşek, 2008, s. 113). Araştırmaya katılan çalışma grubuna ait kişisel bilgiler aşağıdaki tabloda sunulmuştur.

Tablo 1: Çalışma Grubuna Ait Kişisel Bilgiler

\begin{tabular}{|c|c|c|c|c|c|}
\hline \multirow{3}{*}{ Kişisel bilgiler } & & \multicolumn{3}{|c|}{ Çalıșma grubundaki üniversiteler } & \multirow[b]{3}{*}{ Toplam } \\
\hline & & G̈̈ & MKÜ & YYÜ & \\
\hline & & & & & \\
\hline \multirow{3}{*}{ Cinsiyet } & Kiz & 26 & 21 & 12 & 59 \\
\hline & Erkek & 13 & 30 & 28 & 71 \\
\hline & Toplam & 39 & 51 & 40 & 130 \\
\hline \multirow[t]{3}{*}{ Öğretim türü } & 1. ögrretim & 18 & 26 & 24 & 68 \\
\hline & 2. öğretim & 21 & 25 & 16 & 62 \\
\hline & Toplam & 39 & 51 & 40 & 130 \\
\hline
\end{tabular}

GÜ: Gazi Üniversitesi; MKÜ: Mustafa Kemal Üniversitesi; YYÜ: Yüzüncü Yıl Üniversitesi 
http://dx.doi.org/10.23891/efdyyu.2017.18

ISSN:1305-020

Araştırmanın çalışma grubunda Eğitim Fakültesi Türkçe Öğretmenliği 4. sınıf öğrencisi olan 130 Türkçe öğretmen adayı bulunmaktadır. Katılımcılardan 59'u kız, 71'i erkek öğrencidir. Toplamda 68'i 1. öğretim, 62'si 2. öğretim programında öğrenim gören öğrenciye ulaşılmıştır. Katılımcılar araştırmanın amaçları doğrultusunda yapılan tüm uygulamalara katılmışlardır.

Veri toplama araçları ve geliştirilmesi: Verilerin toplanması için 3 farklı yazma formu hazırlanmıştır.

Belirlenen Bir Konuda Paragraf Düzeyinde Metin Yazma Formu, Türkçe öğretmeni adaylarının belirli bir konuya ilişkin paragraf düzeyinde metin yazma becerilerinin belirlenmesi amacıyla hazırlanmıştır. Formda tema, konu, sınıf, amaç ve ana fikir verilmiş ve katılımcılardan ne istendiği ile ilgili bir yönerge hazırlanmıştır. Formun hazırlanmasında 6. sinıf Duygular ve Hayaller temasının mutluluk konulu "Ömür Boyu Mutluluk" metninden hareket edilmiştir. Amaç ve ana fikir bu metinden hareketle araştırmacı tarafindan oluşturulmuştur. Metnin amacı öğrenciye "Mutlu olmak için insanlık adına faydalı işler yapmak gerektiği" fikrini vermektir. Metnin ana fikri ise "Asıl mutluluk bizim sayemizde başkalarının hayatlarının az da olsa iyiye gittiğini görmektir." şeklindedir.

Derse Hazırlık Amacıyla Derste İslenecek Konuya Uygun Metin Yazma Formu, Türkçe öğretmeni adaylarının derste işleyecekleri konulara ilişkin hazırlık metinleri oluşturabilme becerilerini belirlemek amacıyla hazırlanmıştır. Çalışma için 8. sınıf Öğretmen Kılavuz Kitabında yer alan Zaman ve Mekân temasının Zamanın Önemi konulu "Verilen Sözü Tutmak ve Vaktinde İş Yapmak" adlı metinden hareket edilmiş ve metin forma eklenmiştir. Öğretmen adayları yazmak istedikleri metin türü konusunda serbest bırakılmışlardır. Metnin amacı "İşini zamanında yapan insanların her zaman kazançlı olduğu 
http://dx.doi.org/10.23891/efdyyu.2017.18

ISSN:1305-020

ve başarı yolunda ilerlediği fikrini öğrenciye sezdirmek", ana fikri ise "İnsanların sözünde durması ve sözlerini yerine getirmek için çaba göstermesi önemli bir davranıştır." şeklindedir.

Kelimelerin Anlam İnceliklerini Sezdirmek Amacıla Metin Yazma Formu, Türkçe öğretmeni adaylarının kelimelerin anlam inceliklerini sezdirmek amacıyla metin yazma becerilerini belirlemek için hazırlanmıştır. Bu doğrultuda öğretmen adaylarından eş sesli bir kelime seçip bu kelimenin anlam inceliklerini istedikleri metin türünde 5. sınıf düzeyindeki öğrencilere sezdirmek amacıyla metin yazmaları istenmiştir. Eş sesli kelime öğretimine yönelik metin yazma uygulamasına 5. sınıf Türkçe öğretim programındaki kazanımlardan hareketle karar verilmiştir.

Verilerin toplanması: Öncelikle ilgili üniversitelerde öğrencilerin derslerine giren öğretim üyelerinden izin alınmış ve öğrencilerin gönüllüğü doğrultusunda ders saati içinde uygulamalar yapılmıştır. Çalışmanın amacı ve önemi katılımcılara açıklandıktan sonra uygulama formları sırasıyla verilmiş ve neler yapılacağına dair gerekli açıklamalar yapılmıştır. Uygulamalarda gerekli açıklamalar yapıldıktan sonra fırsat eşitliği sağlamak için öğretmen adaylarına belirli bir süre verilmiş ve bu süre içinde metinlerini yazmaları istenmiştir.

Verilerin analizi: Nitel çözümleme tekniği kullanılarak yapılan analizde öncelikle literatür taranmış, araştırmanın amaçları ve veri toplama araçlarından hareketle değerlendirmede nelere dikkat edileceği belirlenmeye çalışılmıştır. İlgili literatür ve 13 öğretmen adayına ait metinlerden hareketle metinleri değerlendirmek için kategoriler oluşturulmuştur. Paragraflar "tutarlılık", "anlaşılırlık ve akıcılık", "amaç ve ana fikir" ve "sınıf düzeyi" kategorilerinde ve bunlara ait alt kategorilerde incelenmiştir. Derse hazırlık amacıyla derste işlenecek konuya uygun yazılan metinler "başlık", "tutarlılık", "anlaşılırlık ve akıcılık", "amaç ve ana fikir", "sınıf düzeyi" ve "metin türü" kategorilerinde ve bunlara ait alt 
http://dx.doi.org/10.23891/efdyyu.2017.18

ISSN:1305-020

kategorilerde; kelimelerin anlam inceliklerini sezdirmek amaciyla yazılan metinler ise "başlık", "tutarlılık", "anlaşılırlık ve akıcılık", "amaç" ve "sınıf düzeyi", "kelime seçimi" ve "metin türü" kategorilerinde ve bunlara ait alt kategorilerde incelenmiştir. Değerlendirme formunda kategoriler ve alt kategoriler açıklanmış ve örneklendirilmiştir. Uzman görüşü alındıktan sonra metinler değerlendirme için hazırlanan formlar aracılığıyla analiz edilmiştir.

Güvenirlik: Metinlerin değerlendirilmesinde kodlayıcılar arası uyuma bakılmıştır. Çalışma evreninin \%10 'unu oluşturan 13 öğretmen adayına ait metinler araştırmacı ve bir alan uzmanı tarafından ayrı ayrı değerlendirilmiştir. Araştırmacılar bağımsız olarak değerlendirme işlemini bitirdikten sonra bir araya gelinmiş ve kodlamalar karşılaştırılmıştır. Kodlayıcılar arası birlik sağlandıktan sonra araştırmacı analize devam etmiştir. Değerlendirmede belirlenen özellik metinde var ise karşısına bir işaret konulmuş, yoksa boş geçilmiştir. Bu işlem sonunda frekanslar belirlenmiştir. Örneğin; "tutarlılık" kategorisinin alt kategorisi olan "tutarsız metin" sayısının 35 olması.

\section{Bulgular}

Öğretmen adaylarının amaca uygun yazdıkları metinlerin tümü başlık, anlaşılırlık ve akıc1lık, sınıf düzeyi, tutarlılık ve amaca uygunluk kategorilerinde değerlendirilmiştir.

Uygulamaların karşılaştırılmalı tabloları ve yorumları aşağıda yer almaktadır. Uygulamalara ilişkin bilgiler şöyledir:

Uygulama 1: Ders konusuyla ilgili paragraf düzeyinde yazılan metinler

Uygulama 2: Ders konusuna hazırlık amacılla yazılan metinler

Uygulama 3: Kelimelerin anlam inceliğini sezdirmek amacıyla yazılan metinler

Aşağıdaki tabloda öğretmen adaylarının ders konusuyla ilgili olarak yazdıkları metinlerin başlık kategorisine göre inceleme sonuçları yer almaktadır.

Tablo 2: Amaca Uygun Yazılan Metinlerin Başlık Açısından Değerlendirilmesi 


\begin{tabular}{lllllll}
\hline & \multicolumn{5}{c}{ Amaca uygun yazılan metinler } \\
\cline { 2 - 7 } Başlık & Uyg. 2(f) & $\mathbf{\%}$ & Uyg. 3(f) & \% & Top. $(\boldsymbol{f})$ & $\mathbf{\%}$ \\
\hline $\begin{array}{l}\text { Etkili ve içerikle uyumlu } \\
\text { başlık }\end{array}$ & 25 & 19.23 & 17 & 13.07 & 42 & 16.15 \\
$\begin{array}{l}\text { İçerikle uyumlu başlık } \\
\text { İcrikle uyumsuz başlık }\end{array}$ & 51 & 39.23 & 36 & & & \\
Başlıksız metin & 18 & 13.84 & 7 & 5.38 & 25 & 9.61 \\
Toplam & 36 & 27.69 & 70 & 53.84 & 106 & 40.76 \\
\hline
\end{tabular}

Öğretmen adaylarının yazdıkları metinlerden derse hazırlık amacıyla yazılan metinler

ve kelimelerin anlam inceliğini öğretmek amacıyla yazılan metinler başlık kategorisinde incelenmiştir. İnceleme sonucuna göre toplam 260 metinden 106'sında başlık olmadığ görülmüştür. Başlık verilen 154 metinden de 87'si içerikle uyumlu, 42'si etkili ve içerikle uyumludur. İncelenen metinlerden yarıya yakınında başlık olmaması metin hakkında okuyucuya kısa ve öz olarak ön bilgi veren başlık konusunda öğretmen adaylarının problemlerinin olduğunu göstermektedir.

\section{Etkili ve içerikle uyumlu bașlik örneği}

"Zamanı Doğru Kullanmamanın Pişmanlı̆̆ı" başlıklı metin incelendiğinde yazar, sorumluluğunu zamanında yerine getirmeyen ve sözünü tutmayan bir kişiden bahsetmektedir (... Kendisine zaman verirse o süre içerisinde ödevini teslim edeceğine söz verdi. ... Ancak Seda o süre zarfinda da getirip ödevi teslim etmedi) Bu sorumsuzluk ve sözünde durmama ilerleyen zamanda kişinin önüne olumsuz bir durum olarak gelmiş ve hayatını olumsuz etkilemiştir (...Seda tezini sundu ancak tezi kabul edilmedi. Çünkü jürinin en etkin üyesi kendisine söz verip yerine getirmediği hocasıydı). Metin genel olarak değerlendirildiğinde başlığın etkili ve içerikle uyumlu olduğu görülmektedir

\section{İçerikle uyumsuz bașlik örneği:}

Ö63 kodlu öğretmen adayına ait "Kırılan Hayaller" başlıklı metin incelendiğinde içerikle uyumsuz olduğu görülmektedir. Metnin içeriğinde piknik yapılan yer anlamına gelen "kır" kelimesi ile fiil anlamındaki "kır-" kelimelerinin anlam farkı verilmiştir. Metinde bir grup arkadaşın kır gezisine gittiği ve çay yaptıkları semaverin kırılmasından bahsedilmektedir 
http://dx.doi.org/10.23891/efdyyu.2017.18

ISSN:1305-020

( $\ddot{U} c ̧$ arkadaş beraberce toplandık kır gezisine gittik... Tutacağım zaman elimin acımasıyla semaveri düşürdüm. Kırıldı). Metnin başlığında "kır-" kelimesine vurgu yapılsa da içerikte hayal kırıklığından bahsedilmemiştir.

Öğretmen adaylarının ders konusuyla ilgili yazdıkları metinler anlaşılırlık ve akıcılık kategorisinde incelenmiş ve inceleme sonuçları aşağıdaki tabloda sunulmuştur.

Tablo 3: Amaca Uygun Yazılan Metinlerin Anlaşılırlık ve Akıcılık Açısından Değerlendirilmesi

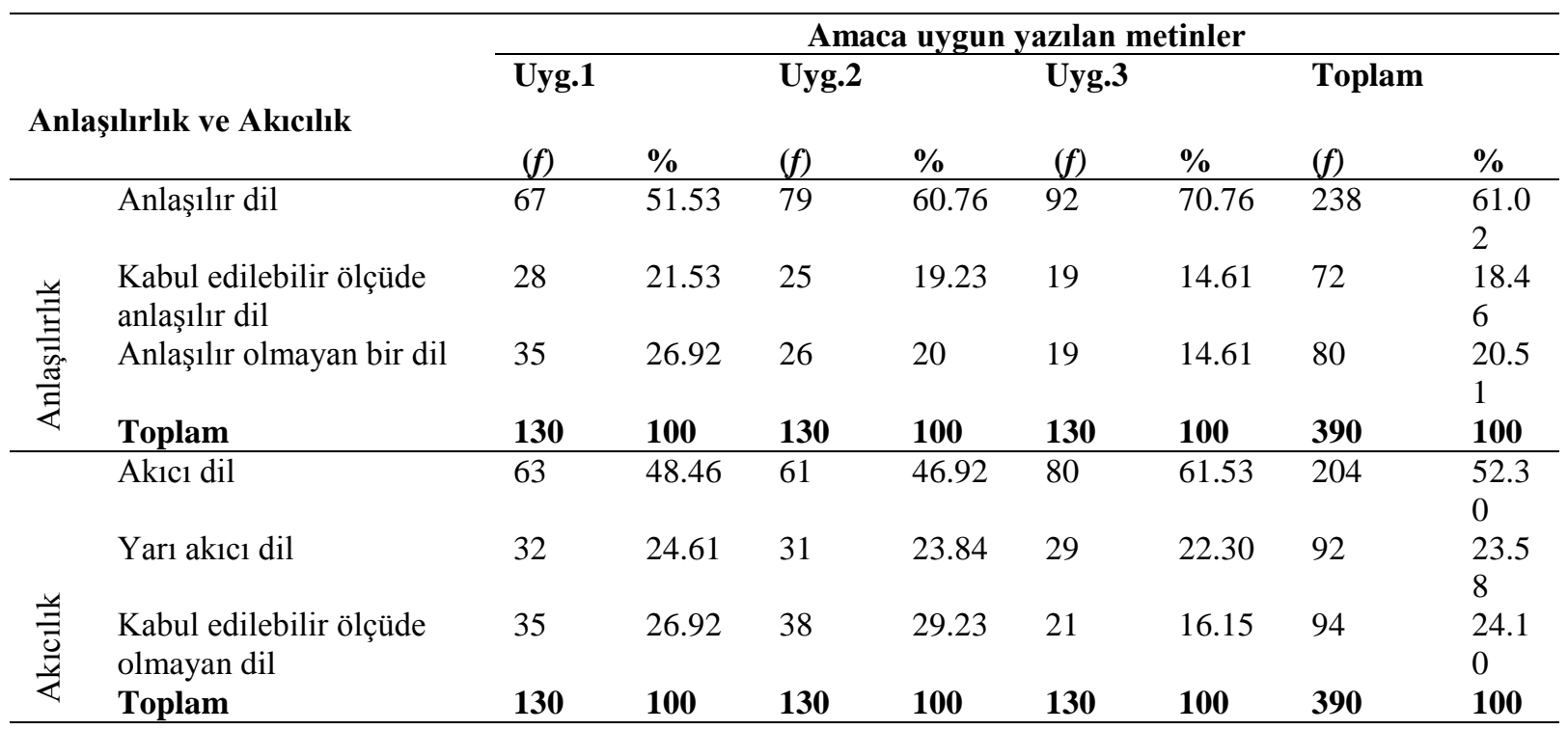

Öğretmen adaylarının yazdıkları metinlerden paragraf düzeyindeki metinler, derse hazırlık amacıyla yazılan metinler ve kelimelerin anlam inceliğini sezdirmek amacıyla yazılan metinler incelendiğinde 390 metinden 238'inde anlaşılır dil, 204'ünde de akıcı dil kullanıldığ1 tespit edilmiştir. Metinlerden 80'inde anlaşılır olmayan dil, 94'ünde de akıc1 olmayan dil kullanılmıştır. Anlatımda anlaşılırlık ve akıcılık açısından en başarılı olan uygulama kelimelerin anlam inceliğini sezdirmek amacıyla yazılan metinlerdir.

Örnek metin: Anlaşı1ır ve akıcı dil kullanılan metin

"Insanların duyguları, hayalleri çeşit çeşittir. Mutluluk dereceleri de kişiden kişiye değişmektedir. Kimi insan evine ekmek götürebildiği için mutlu olurken kimisi ayda krrk kıyafet alsa mutlu olmaz, kimisi içinse mutluluk sadece maddiyattadır. Çevremizde bu örneklerin hepsine rastlarız. Ihtiyaç sahibi birine yardım ettiğinizde aldı̆̆ınız haz, hiçbirine değişilemeyecek kadar büyüktür. Karşımızdaki insanın yerine kendimizi 
http://dx.doi.org/10.23891/efdyyu.2017.18

ISSN:1305-020

koyduğumuzda şartları anlayabilir ve mutluluğu bu yolda bulabiliriz. Aç bir sürü insan varken yaptığımız israfları tersine çevirebilsek tüm insanlığın mutluluğuna da hizmet edeceğimizi düşünüyorum. Yalnı kendimizi değil, insanlı̆̆ düşünerek bu dünyanın daha yaşanılası bir yer olacağı aşikardır."

Yukarıdaki paragraf incelendiğinde kullanılan cümleler anlaşılırdır. (İnsanların duyguları, hayalleri çeşit çeşittir... İhtiyaç sahibi birine yardım ettiğimizde aldığımız haz, hiçbirine değişilemeyecek kadar büyüktür.). Metinde ele alınan konu ve dil okuyucuyu yormadan akıcı bir şekilde ilerlemektedir. Yazar, mutluluğun kişiden kişiye değişen bir olgu olduğundan bahsettikten sonra asıl mutluluk kaynağının insanlara yardım etmek olduğunu vurgulamıştır. İnsanlık adına gösterilen çabanın dünyayı güzelleştireceği üzerinde durmuştur (Yalnız kendimizi değil, insanlı̆̆ düşünerek bu dünyanın yaşanılası bir yer olacă̆ı aşikârdır.) Paragraf genel olarak değerlendirildiğinde anlaşılır ve akıcıdır.

Öğretmen adaylarının ders konusuyla ilgili yazdıkları metinler sınıf düzeyi kategorisinde dil ve içerik açısından incelenmiş ve inceleme sonuçları tabloda sunulmuştur.

Tablo 4: Amaca Uygun Yazılan Metinlerin Sınıf Düzeyi Açısından Değerlendirilmesi

\section{Amaca uygun yazllan metinler}

\begin{tabular}{|c|c|c|c|c|c|c|c|c|c|}
\hline \multirow[t]{2}{*}{$\begin{array}{l}\text { Sinıf } \\
\text { düzeyi }\end{array}$} & & \multicolumn{2}{|l|}{ Uyg1 } & \multicolumn{2}{|c|}{ Uyg2 } & \multicolumn{2}{|c|}{ Uyg3 } & \multicolumn{2}{|c|}{ Toplam } \\
\hline & & $(f)$ & $\%$ & (f) & $\%$ & (f) & $\%$ & f) & $\%$ \\
\hline \multirow{5}{*}{ Dil } & Sinıf düzeyine uygun dil & 74 & 56.92 & 94 & 72.30 & 108 & 83.07 & 276 & 70.76 \\
\hline & $\begin{array}{l}\text { Sinıf düzeyine uygun olmayan } \\
\text { dil }\end{array}$ & 56 & 43.07 & 36 & 27.69 & 22 & 16.92 & 114 & 29.23 \\
\hline & Toplam & 130 & 100 & 130 & 100 & 130 & 100 & 390 & 100 \\
\hline & $\begin{array}{l}\text { Sinıf düzeyine uygun yeterli ve } \\
\text { etkili içerik }\end{array}$ & 49 & 37.69 & 43 & 33.07 & 54 & 41.53 & 146 & 37.43 \\
\hline & $\begin{array}{l}\text { Kabul edilebilir ölçüde sınıf } \\
\text { düzeyine uygun ve yeterli }\end{array}$ & 69 & 53.07 & 67 & 51.53 & 60 & 46.15 & 196 & 50.25 \\
\hline
\end{tabular}


http://dx.doi.org/10.23891/efdyyu.2017.18

ISSN:1305-020

içerik

$\begin{array}{lllllllll}\text { Hem sınıf düzeyine uygun } & 12 & 9.23 & 20 & 15.38 & 16 & 12.30 & 48 & 12.30\end{array}$

İçerik olmayan hem de yetersiz içerik

Toplam

$\begin{array}{lllllll}130 & 100 & 130 & 100 & 130 & 100 & 390\end{array}$

100

Sınıf düzeyi kategorisinde öğretmen adaylarının paragraf düzeyinde, derse hazırlık

amacıyla ve kelimelerin anlam inceliklerini sezdirmek için yazdıkları metinler incelenmiştir.

İncelenen toplam 390 metinden 276'sında kullanılan dilin sınıf düzeyine uygun olduğu

belirlenmiş̧tir. Sınıf düzeyine uygun dil kullanmada öğretmen adayları kelimelerin anlam

inceliğini sezdirmek amacıyla yazdıkları metinlerde (uyg3) diğer uygulamalara oranla daha

başarılı olmuşlardır. Dil açısından sınıf düzeyine uygun olmayan metinler öğrenci seviyesine

göre ağır veya öğrenci seviyesinin altındadır. Metinler içerik açısından incelendiğinde toplam

146 metinde sınıf düzeyine uygun içerik oluşturulmuştur. 196 metin kabul edilebilir ölçüde

sınıf düzeyine uygun ve yeterli içerikte iken 108 metin sınıf düzeyine uygun ama yetersiz içeriktedir.

Örnek metin: Dil ve içerik açısından sınıf düzeyine uygun metin

"Anneannem ellerime bir kaç dal tutuşturarak bunları evin bahçesine özenle ve ilgiyle dikmemi istedi. Şaşkınlıkla niye diye sordum. Bana açtıklarında dünyanın en güzel gülüşünü armağan edecek bir çiçek olduğunu söyledi. "Ama içine sevgini ve sohbetini katmayı unutmayacaksın." dedi üzerine bastıra bastıra.

Şaşkınlık içinde dalları toprağa diktim. Gerektiği gibi suluyor, gübreliyordum. Ama günler geçse de bitkide hiçbir gelişme gözlemleyemiyordum. En sonunda sinirlendim ve öfkeyle bitkiye "Sen nasll bir çiçeksin o kadar bakıyorum, suluyorum büyümüyor, çiçek açmiyorsun, ne kadar nankör çıktın." diye. Bir gün su vermek için bahçeye indiğimde çiçeğin kurumaya başladı̆̆ını gördüm. Bir an aklıma anneannemin söyledikleri geldi: "Sevgi, sohbet ve güler yüz göster kızım." Hemen geç kalmışlı̆̆n verdiği vicdan azabı ve üzüntüyle her bahçeye indiğimle onunla konuştum, güzel sözler söyledim. Fark ediyordum ki her gün daha da büyüyor, yeşilleniyordu. Onu öyle gördükçe yüzümde sıcak gülüşler doğuyordu istemeden. Zaman ilerledikçe merakla çiçek açmasını bekliyordum. Sıcak bir bahar sabahı koşarak bahçeye inip, çiçeğime koştum ve ne göreyim kıpkırmızı, bakmaya doyamadığım bir tomurcuk bir gül bana unutmayacağım gülüşler hediye etti. Anladım ki sevgi ne kadar artarsa güzellik o kadar artiyor."

Metin değerlendirildiğinde dil ve içerik açısından 5. sınıf öğrencilerinin düzeyine uygun olduğu görülmektedir. Dil açısından değerlendirildiğinde cümlelerin kısa, anlaşılır ve birbirini tamamlayacak yapıda oluşturulduğu görülmektedir (... Şaşkınlık içinde dalları topră̆a diktim. Gerektiği gibi suluyor, gübreliyordum...). Metin içerik açısından değerlendirildiğinde kuru bir gül dalının sevgi ve ilgiyle güzel bir çiçeğe dönüştüğü üzerinde 
http://dx.doi.org/10.23891/efdyyu.2017.18

ISSN:1305-020

durulmuştur. Bu bağlamda çiçek olan "gül" ve eylem olan "gül-" kelimelerinin anlam inceliği başarılı bir şekilde verilmiştir (...Onu öyle gördükçe yüzümde slcak gülüşler doğuyordu istemeden... Sıcak bir bahar sabahı koşarak bahçeye inip çiçeğime koştum. Ve ne göreyim kıpkırmızı, bakmaya doyamadı̆̆ım tomurcuk bir gül.). Metin genel olarak değerlendirildiğinde yazarın amacına ulaştı̆̆ 1 görülmektedir.

Öğretmen adaylarının ders konusuyla ilgili yazdıkları metinler tutarlılık kategorisinde incelenmiş ve inceleme sonuçları aşağıdaki tabloda sunulmuştur

Tablo 5: Amaca Uygun Yazılan Metinlerin Tutarlılık Açısından Değerlendirilmesi

\begin{tabular}{|c|c|c|c|c|c|c|c|c|}
\hline \multirow{3}{*}{ Tutarlılık } & & & \multicolumn{6}{|c|}{ Amaca uygun yazlan metinler } \\
\hline & \multicolumn{2}{|c|}{ Uyg.1 } & \multicolumn{2}{|c|}{ Uyg.2 } & \multicolumn{2}{|c|}{ Uyg.3 } & \multicolumn{2}{|c|}{ Toplam } \\
\hline & $(f)$ & $\%$ & $(f)$ & $\%$ & $(f)$ & $\%$ & $(f$ & $\%$ \\
\hline Tutarlı metin & 92 & 70.76 & 101 & 77.69 & 102 & 78.46 & 295 & 75.64 \\
\hline Tutarsız metin & 38 & 29.23 & 29 & 22.30 & 28 & 21.53 & 95 & 24.35 \\
\hline Toplam & 130 & 100 & 130 & 100 & 130 & 100 & 390 & 100 \\
\hline
\end{tabular}

Öğretmen adaylarının amaca uygun yazdıkları metinler incelendiğinde 390 metinden 295'inin tutarlı metin özelliği gösterdiği, 95'inin de tutarsız metinler olduğu görülmektedir. Tutarlılık kategorisinde öğretmen adaylarının en başarılı olduğu uygulama kelimelerin anlam inceliklerini sezdirmek amacıyla yazdıkları metinlerdir (uyg.3). Tutarsız metinlere en çok ( $f=38)$ paragraf düzeyinde yazılan metinlerde (uy1) rastlanmıştır.

Örnek metin: Tutarlı metin örneği

"BIN" TANE BIN

Nasreddin Hoca'yı hepimiz tanıyoruz. Önemli Türk büyüklerimizden kendisi.Hoca, fikralarlyla ünlüdür ancak onun fikraları ĕ̆lendirme amaçlı değil, öğretme amaçlıdır.

Hoca'nın bir de eşeği vardır ve o eşeğe ters binmesiyle meşhurdur. Eşeği ile ilgili nükteleri de bulunmaktadır. Bunlardan hatırladı̆̆ım kadarıla birini anlatayım. Hoca bir gün eşeğin üstüne binmiş gidiyormuş. Görenler "Şuna bak eşeğin üstüne binmiş gidiyor hayvana yazık diye konuşmuşlar." Bunu duyan hoca eşekten inmiş oğlunu bindirmiş, kendisi yürüyormuş. Görenler "Gencecik çocuk binsin, adam yürüsün, böyle olmaz ki!" diye söylenmişler. Hoca duymuş ve inmiş eşekten. Eşeğin yanında yürümeye başlamışlar. Millet yine konuşmuş: "Eşek boş gitsin, bunlar yürüsün, olmaz ki!" diye. Hoca her yaptı̆̆ına kusur bulanlara 
http://dx.doi.org/10.23891/efdyyu.2017.18

ISSN:1305-020

karşı lafinı esirgememiş. Önemli olanın bizim isteklerimiz olduğunu, herkesin sadece kusur bulmak için konuştuğunu vurgulamış.

Eşeğe ters binsen nolur, düz binsen nolur; binmesen yürüsen nolur... Binlerce insan var etrafta, bin tane de laf söylerler. Onların ă̆zını kapayamayacă̆ımıza göre her lafı önemsememeliyiz. bin yıl da yaşasak kimseyi de kendimize benzetemeyeceğimize göre her lafi önemsememeliyiz. Bin yll da yaşasak kimseyi de kendimize benzetemeyeceğimize göre herkesin hayatının kendine göre iyi olduğunu bilerek yaşamalıyız.

Bu metinde eşeğe binmek, binlerce sene, bin yll kelimeleri geçmekte. "Eşeğe binmek" kelime gurubundaki "bin" kelimesi inmek karşıtı olan "bin"dir. Bir şeyin üzerine çıkmak olarak tanımlanır. Binlerce sene ve bin yıl kelime gruplarındaki bin ise sayı olan "bin"dir. Bu kelimelerin yazılışları aynı anda anlamları farklıdır, yanı bunlar eş sesli kelimelerdir."

Yukarıdaki metinde kelimelerin anlam inceliği tutarlı bir biçimde verilmektedir. Metinde Nasreddin Hoca'ya atıf yapılarak bir metin kurgulanmış ve metinde "bin-" fiili ile sayı olan "bin" kelimelerinin anlam farkı başarılı bir şekilde verilmiştir. Yazar metne Nasreddin Hoca ile ilgili bilgi vererek başlamıştır (...Hoca, fikralarıyla ünlüdür ancak onun fikraları eğlendirme amaçlı değil, öğretme amaçlıdır...). Daha sonra Nasreddin Hocayla ilgili bir fikrada sayı olan "bin" ile "bin-" kelimelerinin anlam farkı sezdirilmiştir (...Görenler "Şuna bak eşeğin üstüne binmiş gidiyor, hayvana yazık" diye konuşmuşlar... Binlerce insan var etrafta, bin tane de laf söylerler). Yazar fikrayı anlattıktan sonra "bin" kelimesi "bin-" kelimesinin anlam farkını açıklamışır (..."Eşeğe binmek" kelime grubundaki "bin-" imek karşıtı olan "bin"dir. Bir şeyin üzerine çıkmak olarak tanımlanır. Binlerce sene ve bin yıl kelime gruplarındaki bin ise sayı olan "bin"dir.). Genel olarak değerlendirildiğinde metin tutarlı bir biçimde oluşturulmuş ve kelimelerin anlam inceliği başarılı bir şekilde verilmiştir.

Örnek metin: Tutarsız metin

\section{“SÖZÜMÜ TUTTUM}

Sözünde duran insanlar etraftakiler tarafindan her zaman sevilmişlerdir öyle değil mi?

Insan verdiği sözde durduğu zaman dĭger insanlar arasında güven să̆lar ve bu doğrultuda hem sevgi hem de saygl görür.

Işslerini vaktinde yerine getiren insanlar hiçbir zaman dışlanmazlar. Insan sözünün eri olmalıdır. Söz, bir insanın karakterini de belirler.

Toplum tarafindan kabul gören insanlar da işlerini işlerini vaktinde yapan hiçbir zaman aksatmayan, işine zamanında gelen ve ne söylediğini bilen kişilerdir. 
http://dx.doi.org/10.23891/efdyyu.2017.18

ISSN:1305-020

Bu yüzden söz bir silahtır ă̆ızdan bir kere çıkar. Sözlerinizi söylediğiniz anda onun esiri oluruz ama yeter ki tutalım..."

Metnin girişinde sözünde duran insanların çevreleri tarafından sevildiğinden bahsedilmektedir (Sözünde duran insanlar etrafindakiler tarafindan her zaman sevilmişlerdir öyle değil mi?) Ardından sözünde durmanın bir karakter özelliği olduğu üzerinde durulmuştur (İnsan sözünün eri olmalıdır. Söz bir insanın karakterini de belirler.). Metnin devamında işini vaktinde yapan insanların toplum tarafından kabul gören insanlar olduğunu vurgulanmıştır (Toplum tarafindan kabul gören insanlar da işlerini vaktinde yapan hiçbir zaman aksatmayan, işine zamanında gelen ve ne söylediğini bilen kişilerdir." Yazar metnini sözünde durmanın önemini vurgulayarak sonlandırmıştır. Metin bir bütün olarak değerlendirildiğinde birbirinden farklı iki konunun (sözünde durmak, vaktinde iş yapmak) birbirinden bağımsız düşünceler olarak ele alındığı ve tutarsız metin özelliği taşıdığı görülmektedir.

Öğretmen adaylarının ders konusuyla ilgili yazdıkları metinler amaca uygunluk kategorisinde incelenmiş ve inceleme sonuçları aşağıdaki tabloda sunulmuştur.

Tablo 6: Amaca Uygun Yazılan Metinlerin Amacı Gerçekleştirme Açısından Değerlendirilmesi

\begin{tabular}{|c|c|c|c|c|}
\hline Uygulamalar & Amaç ve ana fikir & Kategoriler & $f$ & $\%$ \\
\hline \multirow{3}{*}{$\begin{array}{l}\text { Ders konusuna uygun } \\
\text { paragraf düzeyinde } \\
\text { metinler }\end{array}$} & \multirow{3}{*}{$\begin{array}{l}\text { Metinde amaç ve ana } \\
\text { fikri yansitma }\end{array}$} & $\begin{array}{l}\text { Amaç ve ana fikri metinde açıkça } \\
\text { söyleme }\end{array}$ & 46 & 35.38 \\
\hline & & $\begin{array}{l}\text { Amaç ve ana fikri metne yedirerek } \\
\text { verme (sezdirme) }\end{array}$ & 41 & 31.53 \\
\hline & & $\begin{array}{l}\text { Amaç ve ana fikirden uzak fakat } \\
\text { konuyla ilgili metin }\end{array}$ & 39 & 30 \\
\hline
\end{tabular}


http://dx.doi.org/10.23891/efdyyu.2017.18

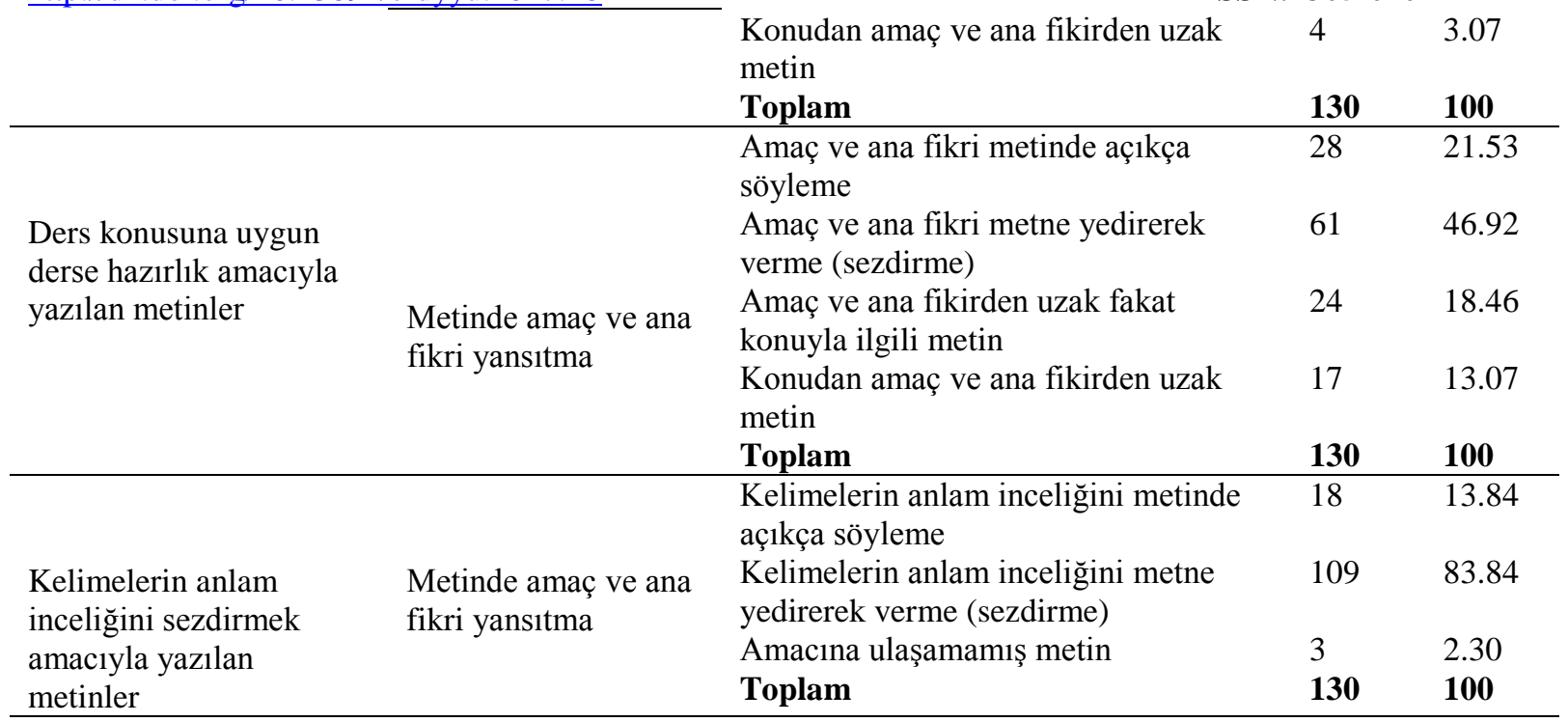

Öğretmen adaylarının amaca uygun yazdıkları metinler incelendiğinde öğretmen adaylarının paragraf düzeyinde yazdıkları metinlerde daha çok amaç ve ana fikri metinde açıkça söylemeyi $(f=46)$ tercih ettikleri görülmektedir. Derse hazırlık amacıyla yazılan metinlerde ise amaç ve ana fikri metne yedirerek vermeyi $(f=61)$ tercih etmişlerdir. Kelimelerin anlam inceliğini sezdirmek amacıyla yazılan metinlerde de öğretmen adayları kelimelerin anlam inceliğini metne yedirerek vermeyi $(f=109)$ tercih etmişlerdir.

Örnek metin: Amaç ve ana fikirden uzak fakat istenen konuyla ilgili metin

"Mutluluk... Insanların yana yakıla aradıkları, dillerinden düşürmedikleri muhteşem olgu. Oturduğumuz yerden "mutluluğu" istemek, çağırmak ne kadar da kolaydır. İsteriz; çünkü istemenin hayal etmenin sinırları yoktur. Etrafi duvarlarla çevrili bir odada koltuğumuzda otururken okuduğumuz kitaptaki Leyla'nın Kağan'ın mutluluğunu kendimizde bulmayı hayal etmek. Peki mümkün mü? Tek başına değil. Her şeyde olduğu gibi "teklik" mutlulukta da işe yaramaz formül. Mutluluk bir oyun ve kesinlikle tek oynanmiyor."

Yukarıdaki paragraf incelendiğinde anlaşılırlık ve akıcılık konusunda sıkıntı olduğu görülmektedir. Metindeki karmaşık cümle yapıları anlaşılırlığı olumsuz etkilemektedir. (Mutsuz olduğumuz anda mutsuzluğumuza sebebiyet veren sorunu iyice düşündüğümüzde çevre ile olan paylaşma sorunu olduğunu, tam olarak bu olmasa da bununla ilintili olduğunu anlayabiliriz). Anlaşılır olmayan dil yapıları doğal olarak akıcılı̆̆ını ve metnin anlamlandırılmasını olumsuz etkilemektedir.

Örnek metin: Amaç ve ana fikrin açıkça söylendiği metin 
http://dx.doi.org/10.23891/efdyyu.2017.18

İşini yarına bırakma sakın.

Yarın ne getirir bize bilinmez.

Zamanında yap, artar kazancin.

Bugünün nimeti yă̆murdur dinmez.

Söz verdiysen saatten ayırma göz.

İtibar düşürür tutulmayan söz.

Sözü tut, işini zamanında çöz.

Adın bir ömür hatırdan silinmez.

Tutmazsan sözünü kırllır kalpler.

Sözünü tutanlara er derler er.

Unutma zamanı, rüzgardır geçer.

Işsi tutan 'geç'in atına binmez.

Şiirde amaç ve ana fikir açıkça söylenerek öğrenciye verilmeye çalışı1mıştır. "İşine yarına bırakma sakın / Yarın ne getirir bilinmez" dizeleriyle işini vaktinde yapmanın önemine vurgu yapmıştır. "Söz verdiysen saatten ayırma göz / İtibar düşürür tutulmayan söz" dizeleriyle de kişinin sözünde durması ve sözünü vaktinde yerine getirmek için çaba göstermesi üzerinde durulmuştur. Şiirin son dörtlüğünde ise söz tutmanın kişinin karakteri ile ilgili olduğu, zamanın rüzgâr gibi hızlı geçtiği ve vaktinde iş yapmanın insanı pişmanlıklardan koruduğu vurgulanmıştır.

\section{Sonuç ve Tartışma}

Öğretmen adaylarının amaca uygun yazdıkları metinlerin tümü başlık, anlaşılırlık ve akıcılık, sınıf düzeyi, tutarlılık ve amaca uygunluk kategorilerinde değerlendirilmiştir. Değerlendirme sonuçlarına göre öğretmen adayları yazıkları metinlerin çoğunluğuna başlık vermesine karşın bu başlıklardan sadece 42'si etkili ve içerikle uyumlu bulunmuştur. İncelenen metinlerden yarıya yakınında metin hakkında okuyucuya kısa ve öz olarak ön bilgi veren başlığın olmaması bu konuda öğretmen adaylarının problemlerinin olduğunu göstermektedir. Ülper (2011) de yaptığı çalışmada öğrencilerin, tutarlılığı belirleyen metinsel 
http://dx.doi.org/10.23891/efdyyu.2017.18

ISSN:1305-020

eylemlerden "Başlık ile metni bağlama" metinsel eylemini gerçekleştirmeye yönelik önemli sorunlar yaşadıklarını ortaya koymuştur. Arıcı'nın (2008) yaptığı üniversite öğrencilerinin yazılı anlatım hatalarını tespit etmeye yönelik çalışmada yazılar başlık açısından değerlendirildiğinde öğrencilerin yazıyla başlık arasında uyum sağlayamama, yazıya başlık koymama, çok uzun başlık koyma gibi sıııntılar yaşadıkları belirlenmiştir.

Öğretmen adaylarının yazdıkları metinler anlaşılırlık ve akıcılık açısından incelendiğinde 390 metinden 238'inde anlaşılır dil, 204'ünde de akıcı dil kullanıldığı tespit edilmiştir. Metinlerden 80'inde anlaşılır olmayan dil, 94'ünde de akıcı olmayan dil kullanılmıştır. Anlatımda anlaşılırlık ve akıcılık açısından en başarılı olan uygulama kelimelerin anlam inceliğini öğretmek amacıyla yazılan metinlerdir. Yapılan araştırmalar incelendiğinde Göçer'in (2010) araştırmasında öğrencilerin yazılı anlatım etkinlikleriyle ortaya koydukları metinler, cümleler arası bağıntı ögelerinin kullanılmasıyla hem anlam zenginliği ve derinliğine ulaşmış hem de farklı amaçlara hizmet eden sözcük örgüsü ile anlatım çeşitliliğine sahip olmuştur. İncelenen metinler metnin yapısı ve paragraf düzeni açısından bakıldığında, giriş, gelişme ve sonuç paragraflarının varlığı ve düzeni; anlatılmak istenen düşüncelerin açık ve anlaşılır oluşu vb. noktalarda genel olarak yeterli bulunmuştur. Bu araştırmanın sonucu ile Göçer'in çalışması birbirini desteklese de bu çalışmada anlaşılır ve akıcı olmayan dil kullanılan metinlerin sayısı bu konuda problemler yaşandığını ortaya koymaktadır.

Sınıf düzeyi kategorisinde öğretmen adaylarının yazdıkları metinler incelenmiştir. İncelenen toplam 390 metinden 276'sında kullanılan dilin sınıf düzeyine uygun olduğu belirlenmiştir. Sınıf düzeyine uygun dil kullanmada öğretmen adayları kelimelerin anlam inceliğini sezdirmek amacıyla yazdıkları metinlerde diğer uygulamalara oranla daha başarılı olmuşlardır. Dil açısından sınıf düzeyine uygun olmayan metinler öğrenci seviyesine göre 
http://dx.doi.org/10.23891/efdyyu.2017.18

ISSN:1305-020

ağır veya öğrenci seviyesinin altındadır. Metinler içerik açısından incelendiğinde toplam 146 metinde sınıf düzeyine uygun yeterli içerik oluşturulmuştur. 108 metin sınıf düzeyine uygun ama yetersiz içeriktedir. Türkçe öğretiminde kullanılacak metinlerin dil ve içerik açısından birtakım özellikleri taşıması özellikle metinlerde kullanılan dilin ve içeriğin sınıf seviyesine uygun olması önemlidir. Fakat önemli oranda metinde hem dil hem de içerik açısından s1kıntılar olduğu görülmektedir.

Öğretmen adaylarının amaca uygun yazdıkları metinler incelendiğinde çoğunluğunun tutarlı metin özelliği gösterdiği, bir kısmının da tutarsız metinler olduğu görülmektedir. Tutarlılık kategorisinde öğretmen adaylarının en başarılı olduğu uygulama kelimelerin anlam inceliklerini sezdirmek amacıyla yazdıkları metinlerdir. Tutarsız metinlere en çok paragraf düzeyinde yazılan metinlerde rastlanmıştır. Çalışmalarda üzerinde durulan metinsellik ölçütlerinden en önemlisi olan tutarlılıkla ilgili çalışan Karatay (2010) Türkçe öğretmen adaylarının yazılı anlatımlarında tutarlı, anlamsal bütünlüğü olan bir metin oluştururken güçlük çekmediklerini belirlemiştir. Ülper'in (2011) araştırmasına göre de tutarlılı̆̆ belirleyen metinsel eylemlerden "Başlık ile metni bağlama" metinsel eylemi başta olmak üzere "Ardışık tümceler arası anlamsal bağlar kurmak", "Metnin giriş, gelişme ve sonuç bölümlerini bağlamak" ve "Konu birliğini sağlamak" gibi metinsel eylemleri gerçekleştirmeye yönelik önemli sorunlar yaşadıkları görülmektedir. Göçer'in (2010) çalışmasına göre ise eğitim fakültesi öğrencilerinin yazılı anlatımlarında ortaya koydukları ürünlerin örnekleme, alıntı ve gönderimler, paragraf düzeni, açık, özgün ve tutarlı anlatım biçimi vb. nitelikler sayesinde bağdaşıklık, tutarlılık, metinlerarasılık gibi metinsellik ölçütlerini taşıdığı sonucuna ulaşılmıştır. 
http://dx.doi.org/10.23891/efdyyu.2017.18

ISSN:1305-020

$\mathrm{Bu}$ çalışmanın sonuçları da öğretmen adaylarının tutarlı metinler oluşturmada başarılı olduğunu göstermektedir. Ancak tutarsız metin sayısı da bu konuda problemler yaşandığını söylemek için önemli bir gerekçe olarak karşımıza çıkmaktadır.

Öğretmen adaylarının amaca uygun yazdıkları metinler amaç ve ana fikri verme şekline göre incelendiğinde öğretmen adaylarının paragraf düzeyinde yazdıkları metinlerde daha çok amaç ve ana fikri metinde açıkça söylemeyi tercih ettikleri görülmektedir. Derse hazırlık amacıyla yazılan metinlerde ise amaç ve ana fikri metne yedirerek vermeyi tercih etmişlerdir. Kelimelerin anlam inceliğini sezdirmek amacıyla yazılan metinlerde de öğretmen adaylarının önemli çoğunluğu kelimelerin anlam inceliğini metne yedirerek vermeyi tercih etmiştir. Literatür incelendiğinde Arıcı'nın (2008) yaptığı üniversite öğrencilerinin yazılı anlatım hatalarını tespit etmeye yönelik çalışmada öğrencilerin ana fikir ve yardımcı fikirleri oluşturmada zorlandıkları, paragrafların ana fikirden uzaklaştığı, düşüncelerin dağınık olduğu ve yazının bir bütün oluşturmadığı görülmüştür.

Yapılan araştırma sonuçlarına göre Türkçe öğretmen adayları derste kullanmak üzere amaca uygun oluşturdukları metinlerde beklenen düzeyde başarı gösterememiştir. Bu noktada öğretmen adaylarının bu konuda yeterli düzeye gelmesi için birtakım ek uygulamalara ihtiyaç vardır. Özellikle üniversitede eğitim aldıkları süreçte amaca uygun yazma bir diğer deyişle ders materyali olarak metin yazma hususunda uygulamalar yapılmalıdır. Öğretmen adaylarına farklı seviyelere hitap edecek düzeyde ve içerikte metinler getirilerek derinlemesine inceleme yapılmalıdır. Türkçe dersi öğretim programında öğretmenlerin metin yazmalarını gerekli kılacak uygulamalar yer almalıdır. Türkçe öğretmenliği programı gözden geçirilerek ders materyali olarak metinlere yönelik içerikte bir ders programa eklenmelidir.

\section{Makalenin Bilimdeki Yeri}

Türkçe ve sosyal Bilimler Eğitimi Bölümü, Türkçe Eğitimi Ana Bilim Dalı 
http://dx.doi.org/10.23891/efdyyu.2017.18

ISSN:1305-020

Makalenin Bilimdeki Özgünlüğü

Bireylere temel dil becerilerini kazandırmayı amaçlayan Türkçe dersleri metinlere dayalı olarak yürütülmektedir. Metinler aracılığıyla bireylere bilgi verilmekte, dili etkin kullanma becerisi kazandırılmaktadır. Bu noktada Türkçe öğretmenlerine metinlerin seçimi, düzenlenmesi, gerekirse yeniden metin yazılması konusunda önemli görevler düşmektedir. Bu nedenle öğretmen adaylarının amaca uygun metin yazma becerilerinin ortaya konulması, bu konuda yaşanan sorunlara 1şık tutması ve programların gözden geçirilmesi için önemlidir.

\section{Kaynakça}

Anılan, H., Kaya, M. F., Bayrak, E. \& Kaynaş, E. (2010). Konu bağımlı ve konu bağımsız yazma çalışmalarının karşılaştırılması. Uşak Üniversitesi Sosyal Bilimler Dergisi 3(1), 103-119.

Arıcı, A. F. (2008). Üniversite öğrencilerinin yazılı anlatım hataları. Uludă̆ Üniversitesi Ĕ̈itim Fakültesi Dergisi, 21 (2), 209-220.

Bağcı, H. (2007). Türkçe öğretmeni adaylarının yazılı anlatım derslerine yönelik tutumları ile yazma becerileri üzerine bir araştırma. (Yayımlanmamış doktora tezi), Gazi Üniversitesi Eğitim Bilimleri Enstitüsü, Ankara. Doktora Tezi.

Bozkurt, S. (2009). Karşılaştırmalı metin türünde yazma edimi. (Yayımlanmamış yüksek lisans tezi), Ankara üniversitesi Sosyal Bilimler Enstitüsü, Ankara. Yüksek Lisans Tezi.

Cansız Aktaş, M. (2014). Nitel veri toplama araçları. Mustafa METíN (Ed.), Ĕgitimde bilimsel araştırma yöntemleri içinde (s. 337-371). Ankara: Pegem.

Ceran, D. (2013). Türkçe öğretmeni adaylarının yazma eğitimi dersine yönelik tutumlarının değerlendirilmesi. TurkishStudies. 8(1), 1151-1169. 
http://dx.doi.org/10.23891/efdyyu.2017.18

ISSN:1305-020

Çeçen, M. A. \&Aytaş, G. (2008). Metne dayalı dil bilgisi öğretiminin

sekizinci

sinif öğrencilerinin dil bilgisi başarısına etkisi. Yüzüncü Yll Üniversitesi Eğitim Fakültesi Dergisi, 5(1), 133-149.

Çoban, A. (2010). Türkçe öğretmenliği lisans programlarının değerlendirilmesi. Turkish Studies 5(3), 958-976).

Demirel, Ö. (1999).İlköğretim okullarında Türkçe öğretimi. İstanbul: Milli Eğitim Bakanlığı.

Duman, A. (2005).Türkçe eğitiminde yazdırma çalışmaları. Türk Dili 654, 542-545.

Erdem, İ. ve Başaran, M. (2010). Mezun oldukları bölümlerin öğretmenlerin dilbilgisi öğretimine ilişkin görüşleri üzerindeki etkisi. Türklük Bilimi Araştırmaları 27,321-39.

Erkul, R. (2007). Cümle ve Metin Bilgisi. Ankara: An1.

Göçer, A. (2010). Eğitim fakültesi öğrencilerinin yazılı anlatım becerilerinin süreç yaklaşımı ve metinsellik ölçütleri ekseninde değerlendirilmesi (Niğde örneği). Kastamonu Eğitim Dergisi, 18(1), 271-290.

Gündoğdu, A. E. (2011). İlköğretim sekizinci sınıf dinleme metinlerinin çeşitli değişkenler açısından incelenmesi. Turkish Studies 6(1), 1217-1227.

Güneş, F. (2013). Türkçe ögrretimi yaklaşımlar ve modeller. Ankara: Pegem.

Güven, A. Z. (2011). İlköğretim ikinci kademe Türkçe öğretim programına ilişkin

Karatay, H. (2007). İlköğretim Türkçe öğretmeni adaylarının okuduğunu anlama becerileri üzerine alan araştırması. (Yayımlanmamış doktora tezi), Gazi Üniversitesi Eğitim Bilimleri Enstitüsü, Ankara. Doktora Tezi.

Karatay, H. (2010). Bağdaşıklık araçlarını kullanma düzeyi ile tutarlı metin arasındaki ilişki. Mustafa Kemal Üniversitesi Sosyal Bilimler Enstitüsü Dergisi, 7(13), 373-385.

Özdemir, E. \& Binyazar, A. (2002). Yazma öğretimi yazma sanatı. İstanbul: Papirüs Pilav, S. \& Ünalan, Ş. (2012). Eğitim fakülteleri için yazılı ve sözlü anlatım. Ankara: Nobel. 
http://dx.doi.org/10.23891/efdyyu.2017.18

ISSN:1305-020

Street, C. \&. Stong, K. K. (2009). In what ways do change teachers' self confidence writers. Teacher education quaterly, Summer, 75-94.

Uygun, M. \& Katrancı, M. (2013). Sınıf öğretmenlerinin Türkçe derslerinde karşılaştıkları sorunlara ilişkin görüşleri. Çankırı Karatekin Üniversitesi Sosyal Bilimler Enstitüsü Dergisi 4(1): 255-270

Ülper, H. (2008). Bilişsel süreç modeline göre hazırlanan yazma öğretimi programının

Ülper, H.(2011). Öğrenci metinlerinin tutarlılık ölçütleri bağlamında değerlendirilmesi. Turkish Studies 6(4), 849-863.

Yıldırım, A. ve Şimşek, H. (2008). Nitel araştırma yöntemi. Ankara: Seçkin. 